\title{
ESTIMATION OF THE PHOSPHOLIPID PHOSPHORUS TURNOVER TIME IN MAN : STUDIES IN NORMAL INDIVIDUALS, IN PATIENTS WITH THE NEPHROTIC SYNDROME AND IN OTHER TYPES OF HYPERLIPEMIA ${ }^{1}$
}

\author{
By HUGO W. MOSER AND KENDALL EMERSON, JR. \\ (From the Department of Medicine, Harvard Medical School and the Medical Clinic, Peter \\ Bent Brigham Hospital, Boston, Mass.)
}

(Submitted for publication December 17, 1954; accepted April 6, 1955)

The purpose of this study is to contribute to an understanding of the mechanism of production of various types of hyperlipemia by comparing the plasma phospholipid turnover time in normal individuals and in patients with elevated plasma lipids. The rate of incorporation of a single tracer dose of $\mathrm{P}^{32}$ labeled carrier-free inorganic phosphate into the plasma phospholipids has been measured and a mathematical procedure described by Zilversmit, Entenman, and Fishler (1) has been used for the calculation of the turnover time of the sum of phospholipid phosphorus contained in the plasma and liver. Results obtained in six normal individuals, in five patients with the nephrotic syndrome and in three patients with hyperlipemia due, respectively, to hypothyroidism, biliary cirrhosis and essential familial xanthomatosis will be presented.

\section{MATERIALS}

All studies were carried out at the Peter Bent Brigham Hospital. Experimental subjects were maintained on normal diet and activity. The subjects selected as normal controls were members of the house staff except for C. K. who was a ward patient. All were free from significant disease.

All patients with the nephrotic syndrome were considered to be in the nephrotic stage of chronic glomerulonephritis and none had azotemia. One of these patients, W. F., was studied on two occasions, marked, respectively, W. F. 1 and W. F. 2. Study W. F. 1 was carried out six weeks after onset of symptoms of the nephrotic syndrome, while study W. F. 2 was carried out three months later. In study W. F. 1, P32 was injected the day after cessation of a five-day course of oral cortisone, $300 \mathrm{mg}$. daily, which had failed to produce a diuresis. In addition, on the 4 th, 5th, and 6 th day following injection of the isotope the patient received 50 grams of albumin intravenously daily. The

1 This study was supported by a grant from the Department of Health, Education and Welfare, Public Health Service. latter therapy, which produced a moderate diuresis, was accompanied by a fall in plasma phospholipid concentration from 18.7 to $13.4 \mathrm{mg}$. per $100 \mathrm{cc}$. Results of study W. F. 1 are thus difficult to interpret; they have been included in this series in order to avoid statistical bias. Studies in the other nephrotics were carried out six months to three years after onset of the disease. Except for study W. F. 1 all experiments in the patients with the nephrotic syndrome were carried out during periods in which the course of their disease was not changing.

Patient H. McC. presented the classical picture of hypothyroidism. Serum protein-bound iodine was 0.8 gamma per $100 \mathrm{cc}$., radioactive iodine uptake was 0 per cent and serum cholesterol was $480 \mathrm{mg}$. per $100 \mathrm{cc}$. Study No. 1 was carried out during a control period, study No. 2 performed after this patient had received $30 \mathrm{mg}$. of thyroid daily for three months. At this time there was marked clinical improvement and serum cholesterol had fallen to $300 \mathrm{mg}$. per $100 \mathrm{cc}$. Patient G. G. had suffered from pruritus, jaundice and progressive weakness for eight months. Physical examination showed intense jaundice, an enlarged, firm liver, palpable spleen tip but no xanthomata. Laboratory studies showed persistent elevation of serum alkaline phosphatase but only slight evidence of hepatocellular damage. Operation two months after onset of symptoms had failed to show extrahepatic biliary obstruction, while pathological findings in the liver were those of pericholangitis and early biliary cirrhosis.

Patient R. Go. presented the classical picture of familial hypercholesterolemia with xanthoma tendinosum, and there was well documented evidence of coronary insufficiency. Her serum cholesterol was $393 \mathrm{mg}$. per 100 cc.

\section{METHODS}

The radioactive phosphorus was obtained from the Oak Ridge National Laboratories as carrier-free $P^{22}$ in the form of dilute phosphoric acid. The isotope was assayed and its identity checked qualitatively with aluminum absorbers. After a portion of the material had been set aside for half-life determination, it was diluted with physiological saline and autoclaved; 1.0 to 2.2 microcuries per kilogram of body weight were then injected intravenously into the experimental subjects, the smaller dosage being used in individuals who received more than 
one injection. No untoward reactions were observed after a total of 26 injections in 22 subjects. In each experimental subject serial specific activity determinations were made of plasma lipid phosphorus and total urine phosphate one or more times daily for 5 to 7 days.

An end window tube Geiger counter with a counting efficiency for $\mathrm{P}^{22}$ of 25 to 30 per cent was used for radioactivity measurements. Background activity varied between 25 and 30 counts per minute. All samples were counted in the dry state, using disposable aluminum planchets. A minimum of 4,000 counts were obtained from each planchet. The radioactivity of all samples obtained later than 12 hours after injection of $\mathrm{P}^{ \pm}$was always more than five times and usually more than ten times background activity. Sample weight varied from 10 to $100 \mathrm{mg}$. A self absorption correction factor, determined experimentally in this laboratory, was applied to all samples. This correction factor did not exceed ten per cent.

Five to $10 \mathrm{cc}$. of heparinized plasma were used for lipid phosphorus specific activity determination. Plasma was separated within ten minutes of removal from the body and lipids were immediately extracted with a chloroform methanol mixture as described by Folch and his co-workers (2), the purification procedure in which the chloroform methanol extract is washed with a large volume of water was not found necessary. The chloroform methanol extract was then filtered and the filtrate was evaporated to dryness at reduced pressure, and at a temperature not exceeding 50 degrees centigrade. The residue was redissolved in about $15 \mathrm{cc}$. of chloroform and aliquots were taken for radioactivity determination and phosphorus analysis. The sample was digested with $\mathrm{H}_{2} \mathrm{SO}_{4}$ and $\mathrm{H}_{2} \mathrm{O}_{2}$ and the phosphorus determination was carried out according to the method of Fiske and Subbarow (3). The sample for radioactivity determination was placed in a centrifuge tube and its volume reduced to about $1 \mathrm{cc}$. by blowing a stream of nitrogen over its surface. This solution was transferred quantitatively to a planchet covered with a circle of lens paper and the chloroform was allowed to evaporate. The sample was then ready for counting. All determinations were performed in duplicate. The mean difference between $\mathbf{5 0}$ duplicate radioactivity determinations was 1.7 per cent with a standard deviation of 1 per cent. In vitro experiments had shown that this procedure allowed excellent separation of inorganic $\mathrm{P}^{22}$ from plasma lipid phosphorus. In these experiments only 0.1 to 0.2 per cent of inorganic $P^{22}$ labeled phosphate added to nonradioactive plasma was present in the lipid extract.

Voided specimens were used for the determination of urine phosphate specific activity. Usually two-hour urine collections were obtained. For the specific activity of total urine phosphate, $1 \mathrm{cc}$. of urine was placed in a planchet, dried slowly under an infra-red lamp and counted. Phosphorus determination was carried out according to the method of Fiske and Subbarow (3). For the specific activity of urine inorganic phosphate the sample was treated with magnesia mixture (4), thus precipitating inorganic phosphate as magnesium am- monium phosphate. The washed precipitate was then dissolved in $0.1 \mathrm{~N} \mathrm{HCl}$ and aliquots of this solution were taken for radioactivity determination and phosphorus analysis. Following precipitation of proteins with trichloracetic acid, the specific activity of plasma inorganic phosphate was measured in the same manner as that of urine inorganic phosphate.

The relationship between the specific activity of plasma inorganic phosphate, urine inorganic phosphate and total urine phosphate was studied in preliminary experiments. These experiments were prompted by the results of Handler and Cohn (5) and Govaerts (6) who found that in dogs subsequent to the first 30 to 90 minutes following injection of $\mathrm{P}^{22}$ the specific activity of plasma inorganic phosphate and urine inorganic phosphate are identical, and also by the fact that almost all urine phosphate is in the form of inorganic phosphate. In our experiments the specific activity of plasma inorganic phosphate was compared with that of urine inorganic phosphate in two normal subjects between 9 and 33 hours after injection of $\mathrm{P}^{22}$. The average difference in five comparisons was 0.6 per cent with a maximum difference of 4 per cent. The specific activity of total urine phosphate and inorganic urine phosphate was compared in a total of twenty specimens from two normal individuals and two patients with the nephrotic syndrome. The average difference was 1.8 per cent with a standard deviation of 1.3 per cent. We have concluded, therefore, that subsequent to nine hours after injection of $\mathrm{P}^{32}$ and possibly before that time, the specific activity of total urine phosphate is equal to that of plasma inorganic phosphate. Use of urine, rather than plasma, to measure the specific activity of inorganic phosphate has made possible more frequent and accurate measurements.

\section{RESULTS}

The experimental data are shown in Table I and the results of certain experiments are presented in Figures 1-5. Specific activity is expressed as

\section{Counts per minute per gram of phosphorus} Counts per minute injected per kg. of body weight the denominator being introduced in order to make results obtained in different experiments more comparable. The most significant results have been plotted in Figures 3 to 5 . It is shown that, in relation to the specific activity of urine phosphate, the specific activity of plasma lipid phosphorus increased more slowly than normal in a nephrotic and in a patient with hypothyroidism, while it appeared to increase at a normal rate in a patient with biliary cirrhosis. These relationships can be compared more quantitatively by calculating the phospholipid turnover time in each instance. 
TABLE I

The specific activity of urine phosphate and plasma lipid phosphorus

\begin{tabular}{|c|c|c|c|c|c|c|c|c|c|c|c|c|c|c|c|}
\hline \multirow[b]{2}{*}{ Patient } & \multirow[b]{2}{*}{ Sex } & \multirow[b]{2}{*}{ Age } & \multirow[b]{2}{*}{ Diagnosis } & \multirow{2}{*}{$\begin{array}{l}\text { Lipid* } \\
\text { phosphorus } \\
\text { Range } \\
m g . \%\end{array}$} & & \multicolumn{10}{|c|}{$\begin{array}{c}\text { Specific activity† } \\
\text { Hours after injection of } P^{32}\end{array}$} \\
\hline & & & & & & 12 & 24 & 36 & 48 & 60 & 72 & 96 & 120 & 144 & 168 \\
\hline P. A. & $\mathbf{M}$ & 24 & Normal & $6.0-7.5$ & $\begin{array}{l}\mathrm{PO}_{4} \ddagger \\
\text { Lipid P }\end{array}$ & $\begin{array}{l}4.38 \\
0.599\end{array}$ & $\begin{array}{l}2.90 \\
1.23\end{array}$ & $\begin{array}{l}2.28 \\
1.53\end{array}$ & $\begin{array}{l}1.85 \\
1.61\end{array}$ & $\begin{array}{l}1.58 \\
1.62\end{array}$ & $\begin{array}{l}1.47 \\
1.56\end{array}$ & $\begin{array}{l}1.25 \\
1.42\end{array}$ & $\begin{array}{l}1.13 \\
1.29\end{array}$ & $\begin{array}{l}1.02 \\
1.17\end{array}$ & 0.942 \\
\hline O. B. & $\mathbf{M}$ & 28 & Normal & $8.7-10.0$ & $\begin{array}{l}\mathrm{PO}_{4} \\
\text { Lipid P }\end{array}$ & $\begin{array}{l}4.13 \\
0.539\end{array}$ & $\begin{array}{l}2.85 \\
1.32\end{array}$ & $\begin{array}{l}2.03 \\
1.64\end{array}$ & $\begin{array}{l}1.72 \\
1.73\end{array}$ & $\begin{array}{l}1.46 \\
1.69\end{array}$ & $\begin{array}{l}1.30 \\
1.64\end{array}$ & $\begin{array}{l}1.12 \\
1.39\end{array}$ & $\begin{array}{l}1.01 \\
1.27\end{array}$ & 0.924 & 0.847 \\
\hline A. $S$. & $\mathbf{M}$ & 24 & Normal & $8.8-10.0$ & $\begin{array}{l}\mathrm{PO}_{4} \\
\text { Lipid P }\end{array}$ & 3.87 & $\begin{array}{l}2.39 \\
1.36\end{array}$ & 1.97 & $\begin{array}{l}1.69 \\
1.59\end{array}$ & 1.53 & $\begin{array}{l}1.36 \\
1.44\end{array}$ & $\begin{array}{l}1.19 \\
1.28\end{array}$ & $\begin{array}{l}1.06 \\
1.11\end{array}$ & 0.963 & \\
\hline C. $\mathrm{K}$. & $\mathbf{M}$ & 29 & Normal & $8.2-9.0$ & $\begin{array}{l}\mathrm{PO}_{4} \\
\text { Lipid P }\end{array}$ & & $\begin{array}{l}2.69 \\
1.01\end{array}$ & 1.25 & $\begin{array}{l}1.91 \\
1.43\end{array}$ & $\begin{array}{l}1.62 \\
1.43\end{array}$ & $\begin{array}{l}1.46 \\
1.47\end{array}$ & $\begin{array}{l}1.25 \\
1.35\end{array}$ & $\begin{array}{l}1.14 \\
1.31\end{array}$ & & \\
\hline R. C. & $\mathbf{M}$ & 27 & Normal & $9.0-9.5$ & $\begin{array}{l}\mathrm{PO}_{4} \\
\text { Lipid P }\end{array}$ & $\begin{array}{l}2.76 \\
0.314\end{array}$ & $\begin{array}{l}2.15 \\
0.774\end{array}$ & $\begin{array}{l}1.80 \\
0.978\end{array}$ & $\begin{array}{l}1.58 \\
1.15\end{array}$ & $\begin{array}{l}1.41 \\
1.16\end{array}$ & $\begin{array}{l}1.28 \\
1.14\end{array}$ & $\begin{array}{l}1.12 \\
1.07\end{array}$ & $\begin{array}{l}1.05 \\
0.964\end{array}$ & 1.00 & 0.956 \\
\hline F. H. & $\mathbf{M}$ & 30 & Normal & $12.4-13.0$ & $\begin{array}{l}\mathrm{PO}_{4} \\
\text { Lipid P }\end{array}$ & 3.48 & $\begin{array}{l}2.49 \\
0.705\end{array}$ & 2.09 & $\begin{array}{l}1.87 \\
1.19\end{array}$ & $\begin{array}{l}1.71 \\
1.27\end{array}$ & $\begin{array}{l}1.57 \\
1.26\end{array}$ & $\begin{array}{l}1.42 \\
1.24\end{array}$ & 1.32 & 1.24 & 1.17 \\
\hline W. F. & $\mathbf{M}$ & 12 & $\begin{array}{l}\text { Nephrotic } \\
\text { syndrome }\end{array}$ & $13.4-20.1$ & $\begin{array}{l}\mathrm{PO}_{4} \\
\text { Lipid P }\end{array}$ & & $\begin{array}{l}5.12 \\
1.03\end{array}$ & $\begin{array}{l}3.78 \\
1.76\end{array}$ & $\begin{array}{l}3.15 \\
2.25\end{array}$ & 2.70 & $\begin{array}{l}2.36 \\
2.32\end{array}$ & $\begin{array}{l}1.85 \\
2.39\end{array}$ & $\begin{array}{l}1.55 \\
2.17\end{array}$ & 1.41 & 1.23 \\
\hline W.F. & $\dot{M}$ & 12 & $\begin{array}{l}\text { Nephrotic } \\
\text { syndrome }\end{array}$ & $25.0-31.5$ & $\begin{array}{l}\mathrm{PO}_{4} \\
\text { Lipid P }\end{array}$ & 7.45 & $\begin{array}{l}4.51 \\
0.386\end{array}$ & 3.60 & $\begin{array}{l}3.08 \\
0.907\end{array}$ & 2.69 & $\begin{array}{l}2.48 \\
1.46\end{array}$ & $\begin{array}{l}2.08 \\
1.88\end{array}$ & $\begin{array}{l}1.89 \\
2.04\end{array}$ & 1.75 & 1.62 \\
\hline A. G. & $\mathbf{M}$ & 39 & $\begin{array}{l}\text { Nephrotic } \\
\text { syndrome }\end{array}$ & $12.1-13.7$ & $\begin{array}{l}\mathrm{PO}_{4} \\
\text { Lipid P }\end{array}$ & & $\begin{array}{l}6.47 \\
1.11\end{array}$ & 4.98 & $\begin{array}{l}4.01 \\
2.04\end{array}$ & $\begin{array}{l}3.59 \\
2.20\end{array}$ & $\begin{array}{l}3.24 \\
2.44\end{array}$ & $\begin{array}{l}2.80 \\
2.48\end{array}$ & $\begin{array}{l}2.49 \\
2.44\end{array}$ & 2.35 & 2.22 \\
\hline B. D. & $\mathbf{M}$ & 19 & $\begin{array}{l}\text { Nephrotic } \\
\text { syndrome }\end{array}$ & $26.9-29.4$ & $\begin{array}{l}\mathrm{PO}_{4} \\
\text { Lipid } \mathrm{P}\end{array}$ & & $\begin{array}{l}6.34 \\
0.764\end{array}$ & 4.37 & $\begin{array}{l}3.50 \\
1.63\end{array}$ & 2.99 & $\begin{array}{l}2.64 \\
2.05\end{array}$ & $\begin{array}{l}2.16 \\
2.09\end{array}$ & $\begin{array}{l}1.87 \\
2.04\end{array}$ & 1.63 & \\
\hline J. P. & $\mathbf{M}$ & 17 & $\begin{array}{l}\text { Nephrotic } \\
\text { syndrome }\end{array}$ & $19.0-23.2$ & $\begin{array}{l}\mathrm{PO}_{4} \\
\text { Lipid P }\end{array}$ & & $\begin{array}{l}4.71 \\
0.728\end{array}$ & $\begin{array}{l}3.38 \\
1.14\end{array}$ & $\begin{array}{l}2.56 \\
1.41\end{array}$ & 2.10 & $\begin{array}{l}1.82 \\
1.55\end{array}$ & $\begin{array}{l}1.46 \\
1.65\end{array}$ & $\begin{array}{l}1.24 \\
1.57\end{array}$ & $\begin{array}{l}1.09 \\
1.48\end{array}$ & $\begin{array}{l}0.959 \\
1.37\end{array}$ \\
\hline R. G. & $\mathbf{M}$ & 16 & $\begin{array}{l}\text { Nephrotic } \\
\text { syndrome }\end{array}$ & $21.8-26.4$ & $\begin{array}{l}\mathrm{PO}_{4} \\
\text { Lipid P }\end{array}$ & 7.71 & $\begin{array}{l}4.73 \\
0.64\end{array}$ & $\begin{array}{l}3.30 \\
1.04\end{array}$ & $\begin{array}{l}2.62 \\
1.27\end{array}$ & 2.20 & $\begin{array}{l}1.95 \\
1.55\end{array}$ & $\begin{array}{l}1.65 \\
1.59\end{array}$ & $\begin{array}{l}1.45 \\
1.61\end{array}$ & $\begin{array}{l}1.28 \\
1.52\end{array}$ & $\begin{array}{l}1.12 \\
1.41\end{array}$ \\
\hline R. Go. & $F$ & 42 & $\begin{array}{c}\text { Familial } \\
\text { hypercho- } \\
\text { lesteremia }\end{array}$ & $14.7-17.3$ & $\begin{array}{l}\mathrm{PO}_{4} \\
\text { Lipid P }\end{array}$ & 4.48 & $\begin{array}{l}3.13 \\
0.896\end{array}$ & 2.37 & $\begin{array}{l}1.98 \\
1.39\end{array}$ & 1.69 & $\begin{array}{l}1.48 \\
1.44\end{array}$ & $\begin{array}{l}1.25 \\
1.34\end{array}$ & $\begin{array}{l}1.16 \\
1.27\end{array}$ & 1.09 & 1.01 \\
\hline G. G. & $F$ & 44 & $\begin{array}{l}\text { Biliary } \\
\text { cirrhosis }\end{array}$ & $45.0-53.1$ & $\begin{array}{l}\mathrm{PO}_{4} \\
\text { Lipid P }\end{array}$ & 0.548 & $\begin{array}{l}3.67 \\
1.35\end{array}$ & 2.68 & $\begin{array}{l}2.29 \\
1.89\end{array}$ & 2.05 & $\begin{array}{l}1.90 \\
1.94\end{array}$ & $\begin{array}{l}1.71 \\
1.95\end{array}$ & $\begin{array}{l}1.55 \\
1.78\end{array}$ & 1.39 & $\begin{array}{l}1.25 \\
1.59 \\
\end{array}$ \\
\hline H. McC. & F & 62 & $\begin{array}{l}\text { Hypothy- } \\
\text { roidism } \\
\text { untreated }\end{array}$ & $18.5-20.2$ & $\begin{array}{l}\mathrm{PO}_{4} \\
\text { Lipid P }\end{array}$ & 0.232 & $\begin{array}{l}5.81 \\
0.689\end{array}$ & $\begin{array}{l}4.42 \\
1.14\end{array}$ & $\begin{array}{l}3.80 \\
1.46\end{array}$ & 3.39 & $\begin{array}{l}3.07 \\
2.02\end{array}$ & $\begin{array}{l}2.52 \\
2.12\end{array}$ & $\begin{array}{l}2.13 \\
2.22\end{array}$ & $\begin{array}{l}1.86 \\
2.17\end{array}$ & $\begin{array}{l}1.64 \\
2.08\end{array}$ \\
\hline H. McC. & $F$ & 62 & $\begin{array}{l}\text { Hypothy- } \\
\text { roidism } \\
\text { treated }\end{array}$ & $11.7-13.4$ & $\begin{array}{l}\mathrm{PO}_{4} \\
\text { Lipid P }\end{array}$ & $\begin{array}{l}7.51 \\
0.578\end{array}$ & $\begin{array}{l}5.06 \\
1.44\end{array}$ & $\begin{array}{l}3.80 \\
2.12\end{array}$ & $\begin{array}{l}3.13 \\
2.42\end{array}$ & $\begin{array}{l}2.73 \\
2.45\end{array}$ & $\begin{array}{l}2.45 \\
2.39\end{array}$ & $\begin{array}{l}2.09 \\
2.34\end{array}$ & $\begin{array}{l}1.89 \\
2.29\end{array}$ & $\begin{array}{l}1.69 \\
2.17\end{array}$ & $\begin{array}{l}1.50 \\
1.94\end{array}$ \\
\hline
\end{tabular}

* "Lipid Phosphorus, Range mg. \%" is the maximum and minimum concentration of plasma lipid phosphorus during the experiment.

† Specific activity is expressed as the ratio Counts per minute per gram of phosphorus

$\ddagger$ "PO" refers to the specific activity of total urine phosphate. For convenience of charting the urine phosphate specific activities shown here are not the experimental values, but have been taken from the curve which gave the best fit for all experimental values in any one patient. The extent to which experimental values deviated from these curves is shown in Figures 1,2 , and 7 .

\section{Calculation of turnover time}

A mathematical treatment described by Zilversmit, Entenman, and Fishler (1) has been employed to calculate the turnover time of the sum of lipid phosphorus contained in the plasma and liver, henceforth referred to as the "plasma-liver pool" of lipid phosphorus. Turnover time is defined as the time required to turn over a quantity of phospholipid phosphorus equal to that present in the pool. It is known that there are several types of phospholipids each with different turnover rates $(7,8)$. Our data give information 
THE SPECIFIC ACTIVITY OF URINE PHOSPHATE AND PLASMA LIPID PHOSPHORUS AF?ER INJECTION OF P32

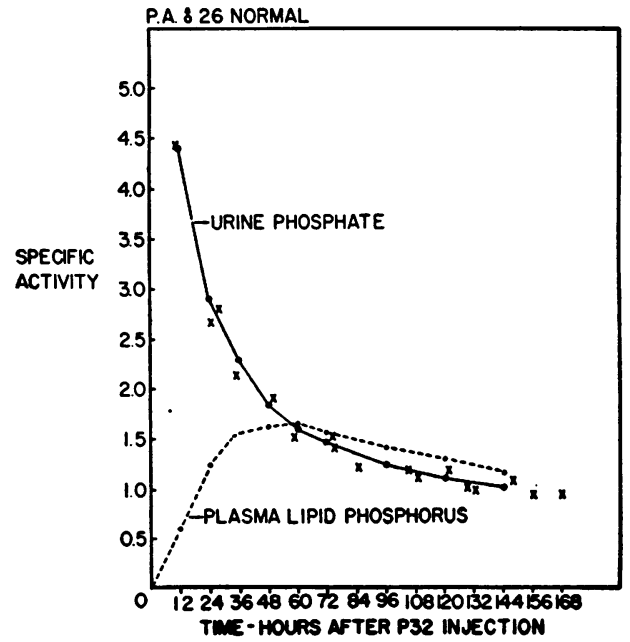

FIgURE 1

Specific activity in this and all other figures is expressed as :

Counts per minute per gram of phosphorus

Counts per minute expressed per kg. of body weight

The crosses indicate experimental values for urine phosphate specific activity. This is one of the experiments where Zilversmit's criteria for an immediate precursor were fulfilled (see text).

only about the average turnover time of these compounds and, furthermore, only about the phosphorus moiety of the molecule. This limitation will be discussed below.

The basic equation in this calculation is :

$$
\frac{\mathrm{dL}}{\mathrm{dt}}=\mathrm{k}(\mathrm{P}-\mathrm{L}),
$$

where

$\mathrm{L}=$ specific activity of lipid phosphorus,

$\mathrm{P}=$ specific activity of urine phosphate,

$\mathrm{k}=$ fraction of lipid phosphorus present in the "plasma-liver pool" turned over per hour,

$\mathrm{t}=$ time in hours.

Equation (1) is similar to a more general equation described by Zilversmit, Entenman, and Fishler (1). They also discussed certain general assumptions necessary for this calculation. To apply this equation to the data of the present study the following additional assumptions are required, due to the fact that the specific activity of
THE SPECFIC ACTIVITY OF URINE PHOSPHATE AND PLASMA LIPID PHOSPORUS AFTER INJECTION OF P32

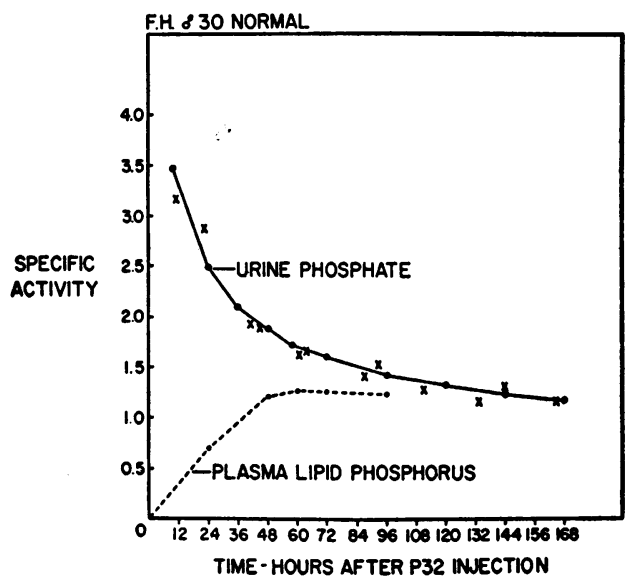

FIgURE 2

This is one of the two experiments where Zilversmit's criteria for an immediate precursor were not fulfilled (see text).

\section{COMPARISON OF THE RATE OF INCREASE OF PLASMA LIPID PHOSPHORUS SPECIFIC ACTIVITY IN A NORMAL INDIVIDUAL AND N A PATIENT WITH THE NEPHROTIC SYNDROME}

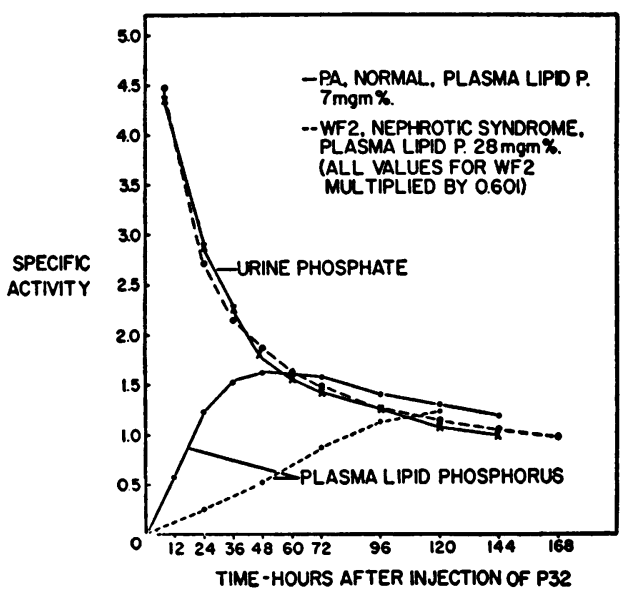

Figure 3

In preparing this figure all specific activity values for patient W. F. 2 were multiplied by 0.601 , this factor being chosen because it made the urine phosphate specific activity curve for this patient and for the other individual shown in the figure almost superimposable. It is evident from the figure, that, in relation to the specific activity of urine phosphate, the specific activity of plasma lipid phosphorus increased much more slowly in the patient with nephrosis than in the normal individual. 
liver inorganic phosphate and lipid phosphorus was not measured. It is assumed that:

1. All plasma phospholipids are both manufactured and destroyed by the liver.

2. Exchange between plasma and liver phospholipids occurs at a rapid rate. In particular, it is assumed that by 24 hours after injection of $\mathrm{P}^{32}$ the specific activity of plasma and liver lipid phosphorus is identical.

3. The specific activity of total urine phosphate is the same as that of the immediate precursor of lipid phosphorus in the "plasma-liver pool."

Assumption No. 1 is based upon experiments performed by Fishler, Entenman, Montgomery, and Chaikoff (9) and Entenman, Chaikoff, and Zilversmit (10) who showed conclusively that in the normal fasting dog virtually all plasma phospholipids are both manufactured in and removed from the circulation by the liver.

Assumption No. 2 is based upon experimental work in dogs by Fishler, Entenman, Montgomery,

\section{COMPARISON OF THE RATE OF NCREASE OF PLASMA LPPD PHOSPHORUS SPECIFIC ACTIVITY IN A NORMAL NDIVIDUAL AND IN A PATIENT WITH BILIARY CIRRHOSIS}

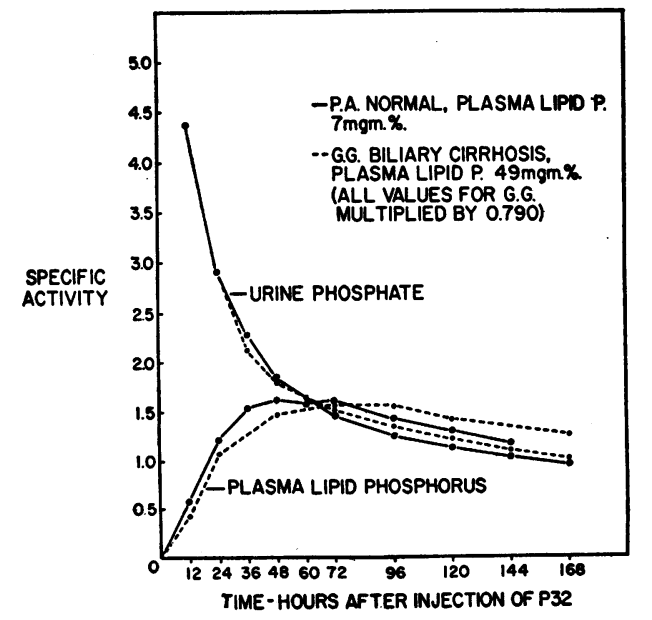

Figure 4

The same procedure for charting was used as in Figure 3 , except that in this instance all specific activity values for patient $G$. G. were multiplied by the factor 0.790 . In spite of the markedly increased plasma phospholipid concentration in patient G. G., the specific activity of plasma lipid phosphorus increased at nearly the same rate as in the normal individual.
COMPARISON OF THE RATE OF NCREASE OF PLASMA LPD PHOSPHORUS SPECIFIC ACTIVITY IN A PATIENT WITH HYPOTHYROIDISM BEFORE AND DURING THYROID THERAPY

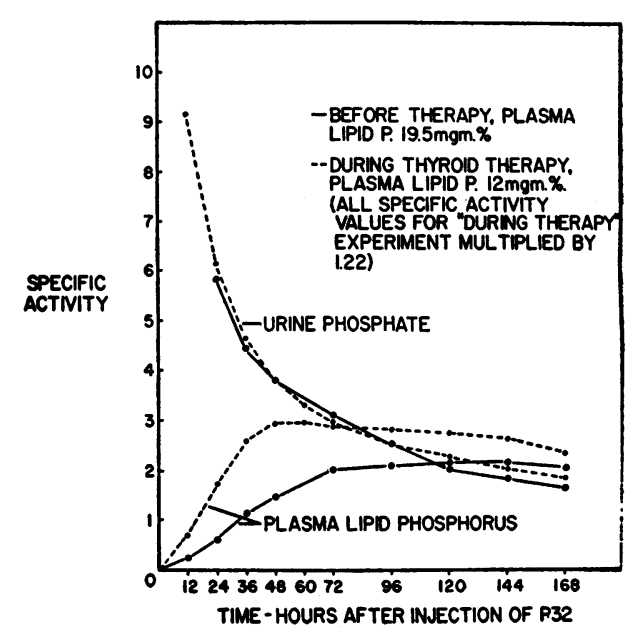

FIGURE 5

The first study in patient $\mathrm{H}$. McC. was carried out during a pre-treatment control period and the second study after therapy with thyroid extract $30 \mathrm{mg}$. a day for three months. In this figure all specific activity values for the "during therapy" study were multiplied by 1.22. It is evident from the figure that, in relation to the specific activity of urine phosphate, the specific activity of plasma lipid phosphorus increased more slowly before therapy than during therapy.

and Chaikoff (9) in which the specific activity of lipid phosphorus in the liver, plasma and certain other tissues was compared following the intramuscular injection of $\mathrm{P}^{32}$ labeled inorganic phosphate. It was found that by eighteen hours after injection of $\mathrm{P}^{32}$ and thereafter, plasma and liver phospholipid phosphorus had nearly identical specific activities. As will be discussed below this assumption may not be justified in the patients with nephrosis.

Assumption No. 3 has been evaluated by review of data available from experimental animals in regard to known intermediates between urine phosphate and the immediate precursor of liver phospholipids. The probable intermediate steps between urine phosphate and the immediate precursor of liver phospholipids are shown in Figure 6. As discussed earlier, equilibrium between the specific activity of plasma inorganic phosphate and urine phosphate is probably established rapidly.

In the rat the specific activity of plasma inor- 
POSSIBLE PATHWAY BY WHICH INTRAVENOUSLY NJECTED P-32 LAEELED INORGANIC PHOSPHATE IS INCORPORATED INTO PI_ASMA PHOSPHOLIPIDES

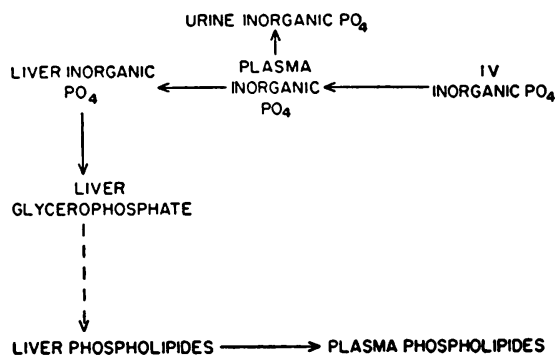

Figure 6

This scheme is based upon results obtained by several authors. As discussed in the text it has been shown in the dog that virtually all plasma phospholipids are manufactured in the liver $(8,9)$. Liver glycerophosphate has been shown to be a likely intermediate by several authors $(8,13,15,16)$. The pathway by which glycerophosphate is incorporated into phospholipids has not been established with certainty.

ganic phosphate and liver inorganic phosphate were found to be nearly the same subsequent to two hours after injection of $\mathrm{P}^{32}(11,12)$. Popjak and Muir (13) and Zilversmit, Entenman, and Chaikoff (8), however, found that the specific activity of liver glycerophosphate is less than that of liver inorganic phosphate up to as long as 24 hours after injection of $\mathrm{P}^{32}$. Zilversmit, Entenman, and Chaikoff (8) and Tolbert and Okey (14) showed in experimental animals that if calculations of turnover time of liver phospholipids are based upon the assumption that liver inorganic phosphate is the immediate precursor of liver phospholipids, resulting values are two to four times as long as when it is assumed that liver glycerophosphate is the immediate precursor. In these studies it was shown that liver inorganic phosphate clearly did not fulfill criteria set out by Zilversmit, Entenman, and Chaikoff and other workers $(8,13)$ for an immediate precursor of liver phospholipids. In our data, however, urine inorganic phosphate fulfilled the criteria for an immediate precursor of plasma phospholipid in eleven out of sixteen experiments in human subjects. In three of our studies (H. McC. 2, A. G., and G. G., Table I) the criteria were not entirely fulfilled, but the deviation was small and may have been due to experimental error, while in only two studies (R. C. and F. H., Table I and Figure 2) the immediate precursor relationship was clearly not fulfilled. These findings suggest that for studies in man, the assumption that inorganic phosphate is an immediate precursor of liver phospholipids does not introduce as large an error in the calculation of phospholipid turnover time as it did in the studies in experimental animals $(8,13)$.

Equation 1 was solved as follows. Using a procedure illustrated in Figure 7, it was found that in all patients the variation of urine phosphate specific activity $(\mathrm{P})$ with time could be expressed as the sum of two exponentials:

$$
\mathrm{P}=\mathrm{Ae^{- \lambda _{1 } t }}+\mathrm{Be}^{-\lambda_{2} t},
$$

\section{THE SPECFIC ACTMTY OF URNE PHOSPHATE AFTER} THE INEEGTION OF P32

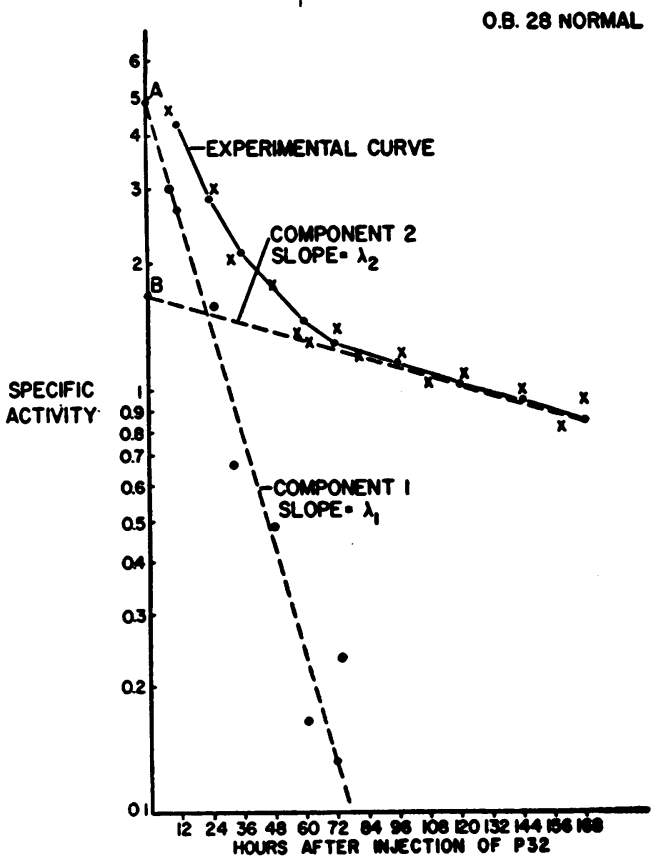

Figure 7

In this figure urine phosphate specific activity is plotted as the ordinate against time in hours on semi-log paper. Experimental points are indicated as crosses. The portion of the experimental curve between 96 and 168 hours was found to form a straight line. This portion of the curve was designated as component 2 with slope lamda 2 , and was extrapolated to 0 -time, as shown in the figure. The difference between the experimental curve and the extrapolated line at corresponding time intervals was determined graphically and plotted, these points being shown as open circles in the figure. Component 1 , with slope lamda 1 , is the straight line which gives the best fit for these points. Points $A$ and $B$ represent, respectively, the intercepts of components one and two with the 0 hour line. Using this procedure urine phosphate specific activity could be expressed by equation 2 (see text). 
TABLE II

VALUES OF CONSTANTS FOR URINE CUHVE USED FOR CaLCULATION OF TUFHOVEK TIME

\begin{tabular}{|c|c|c|c|c|c|c|}
\hline PATIDNT & $A$ & B & \multicolumn{2}{|c|}{ Lande 1} & \multicolumn{2}{|c|}{ Ianda 2} \\
\hline P॰A. & 3.87 & 1.66 & $4.32 \times$ & $10^{-2}$ & $3.44 \times$ & $10^{-3}$ \\
\hline O.B. & 4.94 & 1.49 & 5.03 & $\bullet$ & 3.36 & $\bullet$ \\
\hline A.S. & 5.07 & 1.86 & 7.35 & $\cdot$ & 4.52 & - \\
\hline C.K. & 5.85 & 1.78 & $5.85^{\circ}$ & m & 3.66 & • \\
\hline R.C. & 2.43 & 1.33 & 3.98 & ต & 1.94 & ๓ \\
\hline F.H. & 2.21 & 1.50 & 3.02 & $\bullet$ & 1.41 & - \\
\hline D.F.1 & 7.27 & 3.04 & 4.49 & $n$ & 5.43 & - \\
\hline W.F.2 & 5.77 & 2.48 & 3.95 & ๓ & 2.42 & - \\
\hline A.G. & 9.02 & 3.52 & 4.44 & $n$ & 2.75 & - \\
\hline B.D. & 11.7 & 3.70 & 5.81 & » & 5.73 & $\omega$ \\
\hline R.G. & 10.2 & 2.78 & 6.28 & $n$ & 5.45 & • \\
\hline J.P. & 9.09 & 2.30 & 5.11 & - & 5.21 & - \\
\hline R.Go & 5.22 & 1.57 & 4.53 & 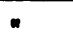 & 2.60 & $n$ \\
\hline G.G. & 5.80 & 2.32 & 5.78 & $n$ & 3.52 & $\bullet$ \\
\hline H.MCC.l & 15.1 & 4.71 & 8.50 & $\varpi$ & 6.48 & - \\
\hline H.MeC.2 & 8.05 & 3.18 & 5.40 & n & 4.44 & - \\
\hline
\end{tabular}

The constants were obtained as described in Figure 7. Theso values were used in our calculation of the Turnover T1n.

The procedure employed in determining these constants is shown in Figure 7. The value of the constants in each experiment is shown in Table II. Equations 1 and 2 are combined :

$$
\frac{d L}{d t}=k\left(A e^{-\lambda_{1} t}\right)+k\left(B e^{-\lambda_{2} t}\right)-k L
$$

Solution of equation 3 is :

$$
\begin{aligned}
L=\frac{k A}{k-\lambda_{1}} e^{-\lambda_{1} t} & +\frac{k B}{k-\lambda_{2}} e^{-\lambda_{2} t} \\
& -\left(\frac{k A}{k-\lambda_{1}}+\frac{k B}{K-\lambda_{2}}\right) e^{-k t}
\end{aligned}
$$

" $k$ " can be found numerically by substitution at any one time, " $t$ " of the experimental values of L, A, B, lamda 1, and lamda 2. Results of this calculation in each patient at $t=24,48,72$, and 96 are shown in Table III. Turnover time is equal to $1 / k$ (" $k$ " represents the fraction of lipid phosphorus turned over per hour).

\section{DISCUSSION}

\section{A. Results in normal individuals}

As shown in Table III, we have calculated that in six normal individuals the average turnover time of phospholipid phosphorus in the "plasmaliver pool" was 75 hours with a range of 60 to 95 .

To estimate the turnover rate of phospholipid phosphorus in the "plasma-liver pool" from these data we have considered the phospholipid phosphorus content of the normal liver to be 2.0 grams (17), while we have used a figure of 0.3 gram for the phospholipid phosphorus content of plasma. The phospholipid phosphorus content of the "plasma-liver pool" would thus be estimated to be 2.3 grams. Turnover rate is equal to

$\frac{\text { Lipid phosphorus content in "plasma-liver pool" }}{\text { Turnover time }}$

It is thus estimated that $2.3 / 75$ or 0.03 gram of lipid phosphorus are turned over per hour.

Weinman, Chaikoff, Entenman, and Dauben (18) found that the turnover times of the fatty acid and the phosphorus moiety of the plasma phospholipid molecule were nearly the same, while Tolbert and Okey (14) showed that the phosphorus and choline moiety of rat liver phospholipids appeared to have the same turnover time. It is thus possible that the turnover time of the phospholipid molecule as a whole is the same as that of the phosphorus moiety. Using the conventional factor of 25 it would thus be estimated that $25 \times .03=0.75$ gram of phospholipid are turned over per hour or 18 grams per day. London and Rittenberg (19) calculated that the half-life time of plasma cholesterol in normal man was eight days. Gould (20) calculated from these data that in a pool consisting of liver, plasma and red cells, 1.2 grams of cholesterol are turned over each day. It would thus appear that phospholipids are turned over much more rapidly than cholesterol.

\section{B. Results in patients with the nephrotic syn- drome}

In six experiments in five patients with the nephrotic syndrome the mean turnover time of phospholipid phosphorus was 159 hours with a range of 97 to 200 hours. The difference between 
TABLE III

CAICULATED VALUES POR "K" AND TOWWOVER TIME (TT)

\begin{tabular}{|c|c|c|c|c|c|c|c|c|c|c|}
\hline PATIBNT & DIAGNOSIS & 2 & $4^{m=\mathrm{Co}}$ & $\begin{array}{r}4 \\
\end{array}$ & $\begin{array}{l}\text { led at I } \\
18 \text {. }\end{array}$ & $\begin{array}{r}\text { Int } \\
72 \\
\end{array}$ & terv & $\begin{array}{r}\text { (hou } \\
96 \\
\end{array}$ & & \\
\hline P.A. & Normal & $1.6 x$ & $10^{-2}$ & $1.7 x$ & $10^{-2}$ & $1.5 x$ & $10^{-2}$ & $1.3 x$ & $20^{-2}$ & 65 \\
\hline O.B. & Normal & 1.6 & $\bullet$ & 1.8 & - & 1.9 & - & 1.4 & $\bullet$ & 60 \\
\hline A.S. & Hormal & 1.7 & $\bullet$ & 1.8 & $\bullet$ & 2.4 & $\bullet$ & 1.2 & - & 66 \\
\hline C.K. & Norwal & 1.0 & $\omega$ & 1.1 & $\bullet$ & 1.1 & - & 1.0 & - & $\mathbf{8 5}$ \\
\hline R.C. & Nornel & 2.3 & $\omega$ & 1.5 & - & 2.3 & - & 1.1 & - & 77 \\
\hline F.H. & Normal & 1.1 & - & 1.3 & $\bullet$ & 1.2 & $\bullet$ & 1.1 & $\bullet$ & 85 \\
\hline K.F. 1 & Nephrosis & 0.6 & $n$ & 1.1 & $\bullet$ & 1.1 & 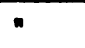 & 1.8 & - & 97 \\
\hline W.F.2 & Nephrosis & 0.3 & 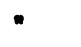 & 0.4 & $\varpi$ & 0.6 & $\bullet$ & 0.8 & - & 189 \\
\hline A.G. & Nephrosis & 0.6 & - & 0.7 & • & 0.8 & $\bullet$ & 0.8 & - & 257 \\
\hline B.D. & Nephrosis & 0.5 & - & 0.6 & • & 0.7 & $\bullet$ & 0.7 & $\bullet$ & 175 \\
\hline $\mathbf{J} \cdot \mathbf{P}$ & Nephrosis & 0.4 & $\bullet$ & 0.7 & $\bullet$ & 0.7 & $\cdot$ & 0.7 & $\bullet$ & 159 \\
\hline R.G. & Nephrosis & 0.3 & $\bullet$ & 0.5 & • & 0.6 & $\bullet$ & 0.6 & - & 800 \\
\hline R.Go. & Hypercholesterolenia & 0.9 & $\bullet$ & 1.1 & $\bullet$ & 1.1 & - & 0.9 & - & 200 \\
\hline G.G. & Biliary Cirrhosis & 1.2 & $\bullet$ & 1.4 & - & 1.4 & - & 1.6 & $\bullet$ & 72 \\
\hline H.MeC.I & $\begin{array}{l}\text { Bypothyroidian } \\
\text { untreated }\end{array}$ & 0.3 & $\varpi$ & 0.5 & & 0.6 & $\bullet$ & 0.6 & $\bullet$ & 200 \\
\hline H.MeC.2 & $\begin{array}{l}\text { Hypothyroldiso } \\
\text { treated }\end{array}$ & 0.9 & - & 1.2 & $\bullet$ & 1.1 & - & 1.1 & $\bullet$ & 93 \\
\hline
\end{tabular}

"k" is the fraction of the phospholipia phosphorus in the "plasea-liver pool" turned over per bour. The value for "Turnover Tlee" shown in this figure is equal to the reciprocal of the wean of the four values of wk. Turhover Tim is expressed in bours.

these results and those in the normals was found to be highly significant statistically ( $P$ less than 0.01 ). This result is consistent with the finding of London, Sabella, and Yamasaki that in a patient with the nephrotic syndrome the half-life time of plasma cholesterol was prolonged (21).

It can be seen in Table III, that in the normals the value of " $k$ " in any one individual is relatively constant. In the patients with nephrosis and in the patient with hypothyroidism, however, the value of " $k$ " calculated at 24 hours is consistently lower than that at later time intervals. This finding indicates that one or more of the assumptions made was not justified in these patients, since if all the assumptions were correct " $k$ " should be constant for each individual. It should be noted, however, that our calculations are based entirely upon the relationship between the simultaneous specific activities of urine phosphate and plasma lipid phosphorus and, even if all the assumptions are discarded, it is still possible to use the calculated value of turnover time as a measure of this relationship. These results thus give statistical confirmation of what was shown graphically in Figure 3, namely, that in relation to the specific activity of urine phosphate, the specific activity of plasma lipid phosphorus increased more slowly in the patients with nephrosis than in the normal individuals.

The slower than normal increase in plasma lipid phosphorus specific activity in these patients may be explained by one of the three following hypotheses:

1. Delay in isotopic equilibrium being reached between urine phosphate and the immediate precursor of liver phospholipids.

2. If we accept the assumptions made for our calculation, a prolonged turnover time of phospholipids in the "plasma-liver pool."

3. Delay in the establishment of isotopic equilibrium between plasma and liver phospholipids.

Hypothesis 1 would indicate abnormal metabolism of the precursors of liver phospholipids. There is at present no evidence for this hypothesis. 
According to Hypothesis 2 our data indicate a prolonged turnover time of lipid phosphorus contained in the "plasma-liver pool." Although no data are available on the phospholipid content of the liver in patients with the nephrotic syndrome, Bally and Emerson (22) have shown that in rats with nephrotoxic nephritis the phospholipid content of the liver is normal even in the presence of marked hyperlipemia. If we assume a value of 0.6 gram (twice normal) for the lipid phosphorus content of plasma, a value of 2 grams (normal) (17) for the lipid phosphorus content of the liver, and 159 hours as the turnover time (the average value in our six experiments), it could be calculated that the patients with nephrosis turned over $(2+0.6$ gram $) / 159$ hours $=0.016$ gram of lipid phosphorus per hour, approximately half the normal amount. However, for reasons discussed below we do not favor this interpretation.

According to Hypothesis 3, the slow increase in plasma phospholipid specific activity is due to delay in isotopic equilibrium being reached between plasma and liver phospholipids. Bearing in mind the observation $(9,10)$ that virtually all plasma phospholipids are both manufactured and removed from the circulation by the liver, this would mean that the turnover time of plasma phospholipids is prolonged without there necessarily being any abnormality in the turnover time of liver phospholipids.

This hypothesis could explain the variation of the calculated values in the nephrotics of the fraction of lipid phosphorus in the pool turned over per hour (k) as shown in Table III. It will be noted that in each of the nephrotics " $k$ " is lower at 24 hours than at later time intervals. It can be shown by substituting various values for " $k$ " in Equation 4, that it usually varies in the same direction as the specific activity of lipid phosphorus (L). Since the liver is the main source of plasma phospholipids, it would be expected, and it.was indeed found to be the case in the dog (9), that before isotopic equilibrium is reached the specific activity of plasma phospholipids is less than that of liver phospholipids. Delay in the establishment of this equilibrium thus could explain the observed variation in " $k$."

Hiller, Linder, Lundsgaard, and Van Slyke (23) found a greater than normal increase in plasma lipids in patients with nephrosis after a fat meal and Stanley and Thannhauser (24) found that following oral administration of $I^{131}$ labeled olive oil, radioactivity in plasma lipids reached a higher peak and disappeared more slowly in a patient with nephrosis than in normal individuals. If it is assumed that fat absorption in nephrosis is normal and that the administered fat was completely mixed with plasma lipids, then both of these experiments indicate that in nephrosis a smaller than normal fraction of plasma lipids is removed from the circulation per unit time. These experiments are in agreement with $\mathrm{Hy}$ pothesis 3, namely, that there is a delay in the attainment of isotopic equilibrium between plasma and liver phospholipids.

As noted earlier our results apply only to the average turnover time of total lipid phosphorus. Zilversmit, Entenman, and Chaikoff (8) found that in the liver of the dog lecithin is turned over more rapidly than cephalin or sphingomyelin. A marked change in the composition of phospholipids alone could thus conceivably account for our findings. Albrink (25) found that in the plasma from two patients with nephrosis the ratio of choline to non-choline containing phospholipids was normal, but she did not determine the ratio of lecithin to sphingomyelin. Further data on the composition of phospholipids in nephrosis as well as turnover studies of separate types of phospholipids would thus be of interest.

\section{Results in other types of hyperlipemia}

In one patient with untreated hypothyroidism the turnover time of phospholipid phosphorus was calculated to be 200 hours, while in the same patient during thyroid therapy it was calculated to be 93 hours. This finding is in agreement with results obtained in experimental animals by Flock, Bollman, and Berkson (12) and data on cholesterol synthesis in hypo- and hyperthyroid rats by Byers, Rosenman, Friedman, and Biggs (26). Since our studies in hypothyroidism are confined to one patient they are not suitable for statistical analysis. However, results in this patient appeared to be similar to those in the patients with the nephrotic syndrome.

The value for turnover time calculated in the patient with familial hypercholesterolemia was intermediate between that in the normals and the patients with nephrosis. 
In our one patient with biliary cirrhosis it was calculated that the phospholipid phosphorus turnover time was within normal limits. In this patient the plasma phospholipid concentration was markedly increased. If it is assumed that the phospholipid content of the liver in this patient was not less than normal, it would be concluded that the phospholipid content of the "plasma-liver pool" was larger than normal. It seems likely, therefore, that in this patient a larger than normal quantity of phospholipid phosphorus was turned over per unit time. No conclusions are warranted, of course, from studies in one patient. It is of interest, however, that this finding is in agreement with those of Balfour (27) in a group of patients including ten individuals with hyperlipemia due to liver or biliary disease. It is, therefore, suggested that the mechanism of hyperlipemia due to liver disease or biliary obstruction is different from that in the nephrotic syndrome.

\section{SUMMARY}

1. In six normal individuals and in eight patients with hyperlipemia, the specific activity of plasma lipid phosphorus and urine phosphate was measured following the intravenous injection of $\mathrm{P}^{32}$ labeled inorganic phosphorus.

2. Turnover time of phospholipid phosphorus contained in the plasma plus liver was calculated from these data and in six normal individuals this was estimated to be 60 to 95 hours.

3 . In the patients with nephrosis and in a patient with untreated hypothyroidism the specific activity of plasma lipid phosphorus, in relation to that of urine phosphate, increased more slowly than in normal individuals, while in a patient with biliary cirrhosis it increased at a nearly normal rate. Intermediate values were obtained in one patient with familial hypercholesterolemia.

4. It is suggested that the most likely interpretation of the findings in the patients with nephrosis is a delay in the attainment of isotopic equilibrium between plasma and liver phospholipids.

\section{ACKNOWLEDGMENT}

The authors wish to express their appreciation to Doctors Isidore Edelman and Arthur K. Solomon for their invaluable advice and criticism. We are also indebted to Doctor Solomon for permission to use the equipment of the Biophysical Laboratory at the Harvard Medical School for the radioactivity determinations.

\section{REFERENCES}

1. Zilversmit, D. B., Entenman, C., and Fishler, M. C., On the calculation of "turnover time" and "turnover rate" from experiments involving the use of labeling agents. J. Gen. Physiol., 1943, 26, 325.

2. Folch, J., Ascoli, I., Lees, M., Meath, J. A., and LeBaron, F. N., Preparation of lipide extracts from brain tissue. J. Biol. Chem., 1951, 191, 833.

3. Fiske, C. H., and Subbarow, Y., The colorimetric determination of phosphorus. J. Biol. Chem., 1925, 66,375 .

4. Umbreit, W. W., Burris, R. H., and Stauffer, J. F., Manometric Techniques and Tissue Metabolism. Minneapolis, Burgess Publishing Company, 1949, p. 208.

5. Handler, P., and Cohn, D. V., Use of radiophosphorus in studies of glomerular permeability of plasma inorganic phosphate. Am. J. Physiol., 1951, 164, 646.

6. Govaerts, J., Urinary excretion of phosphate with ${ }_{15}^{32} \mathrm{P}$ as indicator. Nature, 1947, 160, 53.

7. Levenson, S. M., Adams, M. A., Rosen, H., and Laskey-Taylor, F. H., Studies in phosphorus metabolism in man. III. The distribution, exchange and excretion of phosphorus in man using radioactive phosphorus $\left(\mathrm{P}^{\mathrm{x}}\right)$ as a tracer. J. Clin. Invest., 1953, 32, 497.

8. Zilversmit, D. B., Entenman, C., and Chaikoff, I. L., The measurement of turnover of the various phospholipides in liver and plasma of the dog and its application to the mechanism of action of choline. J. Biol. Chem., 1948, 176, 193.

9. Fishler, M. C., Entenman, C., Montgomery, L. M., and Chaikoff, I. L., The formation of phospholipid by the hepatectomized dog as measured with radioactive phosphorus. I. The site of formation of plasma phospholipids. J. Biol. Chem., 1943, 150, 47.

10. Entenman, C., Chaikoff, I. L., and Zilversmit, D. B., Removal of plasma phospholipids as a function of the liver: The effect of exclusion of the liver on the turnover rate of plasma phospholipids as measured with radioactive phosphorus. J. Biol. Chem., 1946, 166, 15.

11. Sachs, J., Phosphate transport and turnover in the liver. Arch. Biochem., 1951, 30, 423.

12. Flock, E. V., Bollman, J. L., and Berkson, J., Effect of thyroxine and thiouracil on the rate of phospholipid turnover in the liver of the rat. Am. J. Physiol., 1948, 155, 402.

13. Popjak, G., and Muir, H., In search of a phospholipin precursor. Biochem. J., 1950, 46, 103.

14. Tolbert, M. E., and Okey, R., The relative rates of renewal of choline and phosphate in liver phospholipide in the rat. J. Biol. Chem., 1952, 194, 755.

15. Kennedy, E. P., Synthesis of phosphatides in isolated mitochondria. J. Biol. Chem., 1953, 201, 399. 
16. Kornberg, A., and Pricer, W. E., Jr., Enzymatic esterification of $\alpha$-glycerophosphate by long chain fatty acids. J. Biol. Chem., 1953, 204, 345.

17. Man, E. B., Kartin, B. L., Durlacher, S. H., and Peters, J. P., The lipids of serum and liver in patients with hepatic diseases. J. Clin. Invest., 1945, 24, 623.

18. Weinman, E. O., Chaikoff, I. L., Entenman, C., and Dauben, W. G., Turnover rates of phosphate and fatty acid moieties of plasma phospholipides. J. Biol. Chem., 1950, 187, 643.

19. London, I. M., and Rittenberg, D., Deuterium studies in normal man: I. The rate of synthesis of serum cholesterol. II. Measurement of total body water and water absorption. J. Biol. Chem., 1950, 184, 687.

20. Gould, R. G., Lipid metabolism and atherosclerosis. Am. J. Med., 1951, 11, 209.

21. London, I. M., Sabella, G. F., and Yamasaki, M. M., Studies on the metabolism of cholesterol in normal man and in the nephrotic syndrome. J. Clin. Invest., 1951, 30, 657.

22. Bally, P., and Emerson, K., Jr., To be published.

23. Hiller, A., Linder, G. C., Lundsgaard, C., and Van Slyke, D. D., Fat metabolism in nephritis. J. Exper. Med., 1924, 39, 931.

24. Stanley, M. M., and Thannhauser, S. J., The absorption and disposition of orally administered $\mathrm{I}^{\mathrm{p}}{ }_{-}$ labeled neutral fat in man. J. Lab. \& Clin. Med., 1949, 34, 1634.

25. Albrink, M. J., The choline-containing phospholipids of serum. J. Clin. Invest., 1950, 29, 46.

26. Byers, S. O., Rosenman, R. H., Friedman, M., and Biggs, M. W., Rate of cholesterol synthesis in hypo- and hyperthyroid rats. J. Exper. Med., 1952, 96, 513.

27. Balfour, W. M., Human plasma phospholipid formation: A study made with the aid of radiophosphorus. Gastroenterology, 1947, 9, 686. 